\title{
PELATIHAN DALAM PENGGUNAAN INFORMED CONSENT PADA FASILITAS PELAYANAN KESEHATAN
}

\author{
Arief Setiyoargo'), Romaden Marbun"1), Richard One Maxelly1) \\ 1)Program Studi D-IV Manajemen Informasi Kesehatan, STIKes Panti Waluya Malang, Malang, Jawa Timur, Indonesia \\ Corresponding author : Arief Setiyoargo \\ E-mail : setiyoargoarief@gmail.com
}

\section{Diterima 27 Oktober 2021, Direvisi 22 November 2021, Disetujui 22 November 2021}

\begin{abstract}
ABSTRAK
Kegiatan Pengabdian kepada Masyarakat ini bertujuan untuk meningkatkan kualitas pelayanan kesehatan melalui pemahaman penggunaan informed consent. Kegiatan ini diawali dengan penilaian awal kondisi terkini di lapangan di fasilitas pelayanan kesehatan melalui petugas kesehatan/kader kesehatan dan warga. Asesmen awal menemukan masih kurangnya pengetahuan masyarakat tentang penanganan medis bagi pasien dan pengetahuan terkait penggunaan informed consent di fasilitas kesehatan terutama pada masa pandemi Covid-19 saat ini, fokus pelayanan kesehatan masih berpusat pada kesehatan. protokol atau jarak fisik. Kegiatan diawali dengan penyusunan rencana dan jadwal kegiatan serta perlengkapan yang diperlukan. Pelaksanaan kegiatan dilakukan dengan memberikan penyuluhan dan pendampingan yang dikemas dalam bentuk materi dan video yang dibagikan melalui google drive secara serta diskusi secara online melalui grup WhatsApp. Kegiatan diakhiri dengan evaluasi menggunakan google form. Hasil kegiatan pengabdian masyarakat terdapat sebanyak $57,69 \%$ pemahaman warga dalam kategori baik, 26,92\% cukup dan 15,38\% kurang. Kegiatan berjalan dengan baik dan perlu pemantauan lebih lanjut.
\end{abstract}

Kata kunci: tenaga kesehatan; pasien; informed consent.

\begin{abstract}
This Community Service activity aims to improve the quality of health services through understanding the use of informed consent. This activity begins with an initial assessment of the current state of the field in health care facilities through health workers/health cadres and residents. The initial assessment found that there was still a lack of public knowledge about medical treatment for patients and knowledge related to the use of informed consent in health facilities, especially during the current Covid-19 pandemic, the focus of health services is still centered on health protocols or physical distancing. The activity begins with preparing a plan and schedule of activities as well as the necessary equipment. The activities are carried out by providing counseling and assistance packaged in the form of materials and videos that are distributed via Google Drive as well as online discussions through WhatsApp groups. The activity ended with an evaluation using a google form. The results of community service activities there are as many as $57,69 \%$ of citizens' understanding in the good category, $26,92 \%$ sufficient and $15,38 \%$ less. Activities are going well and need further monitoring.
\end{abstract}

Keywords: health worker; patient; informed consent

\section{PENDAHULUAN}

Kesehatan merupakan salah satu faktor terpenting dalam pelaksanaan pembangunan nasional karena merupakan kebutuhan yang sangat mendasar setiap warga negara. Dalam pelaksanaannya saat ini di Indonesia masih banyak dijumpai masalah dalam bidang kesehatan. Hal ini terlihat dari rendahnya tingkat kesehatan masyarakat. Kondisi ini khususnya terjadi pada golongan masyarakat menengah ke bawah.

Dinamika kehidupan masyarakat juga berlangsung pada aspek kesehatan, sehingga kadang muncul kelalaian dan terbengkalainya hak dan kewajiban antara pasien dengan dokter/tenaga kesehatan. Kesalahan dan atau kelalaian yang dilakukan oleh seorang tenaga kesehatan, dapat dituntut secara pidana apabila memenuhi unsur-unsur pidana, dalam hukum pidana, dan juga secara perdata, dimana pasien dapat mengajukan tuntutan atau klaim ganti rugi terhadap dokter (Sitohang, 2017).

Untuk menyelesaikan masalah-masalah kesehatan tersebut, pemerintah telah melakukan berbagai upaya dalam meningkatkan pelayanan kesehatan masyarakat, baik melalui pembangunan 
fasilitas kesehatan, pemberian pelayanan kesehatan secara cuma-cuma maupun produk hukumnya. Di kalangan profesi hukum dan kedokteran telah terdapat aturan yang memberikan perlindungan terhadap masyarakat sebagai pasien yang menerima pelayanan kesehatan yang didasarkan atas informasi yang diberikan oleh pihak rumah sakit melalui seorang dokter. Berdasarkan hal tersebut, maka dalam berbagai upaya penyembuhan kesehatan harus ada persetujuan dari pasien atas dasar informasi dari dokter di rumah sakit tersebut, atau disebut dengan informed consent.

Persetujuan Tindakan Kedokteran atau informed consent adalah salah satu bagian dari Tindakan Kedokteran. Tindakan kedokteran merupakan tindakan hukum yang terjadi karena adanya hubungan hukum antara dokter dan pasien sebagai akibat dari perikatan/perjanjian antara dokter dan pasien (Dali, Muh Amin, 2019). Persetujuan dapat diberikan baik secara tertulis maupun lisan. Terhadap tindakan kedokteran yang mengandung risiko tinggi harus diberikan dengan persetujuan tertulis yang ditanda tangani oleh yang berhak memberikan persetujuan (DPR RI, 2004). Kesepakatan terjadi pada saat pasien atau orang yang berhak memberikan persetujuan terhadap tindakan medis yang akan dilakukan oleh dokter atau dokter gigi ditandatangani. Ketika pasien atau orang yang berhak memberikan persetujuan menandatangani informed consent, maka terjadilah kesepakatan diantara dokter dan pasien.

Karena informed consent merupakan perjanjian untuk melakukan tindakan medis, maka keberadaan informed consent sangat penting bagi para pihak yang melakukan perjanjian pelayanan kesehatan, sehingga keberadaan informed consent sangat penting dan diperlukan di rumah sakit. Dengan adanya informed consent, pasien dapat dilindungi dari kesewenang-wenangan dokter ataupun pihak rumah sakit.

Perkembangan jumlah penduduk pada suatu kawasan membawa perubahan besar pada kebutuhan dasar manusia yaitu kebutuhan akan sandang, pangan dan papan serta fasilitas penunjangnya. Kebutuhan dasar tersebut terus meningkat secara alamiah seiring kompleksitasnya kebutuhan hidup bermasyarakat seperti aktivitas sosial, aktivitas ekonomi dan aktivitas pelayanan umum. Dari kondisi tersebut menuntut adanya pembangunan sarana dan prasarana pada suatu kawasan guna menjaga kelangsungan hidup masyarakat terutamanya di daerah perkotaan. Salah satunya yaitu kebutuhan akan sarana atau fasilitas pelayanan kesehatan sebagai bentuk kebutuhan dasar manusia dalam mempertahankan keberlangsungan hidupnya. Fasilitas pelayanan kesehatan memberikan banyak manfaat diantaranya memberikan pelayanan promotif, preventif, kuratif dan rehabilitatif serta edukasi kesehatan kepada masyarakat.

Pada masa pandemi Covid 19 saat ini yang sedang melanda Indonesia dan dunia juga turut memberikan dampak di berbagai daerah di tanah air. Covid 19 bukan hanya merupakan suatu wabah biasa, melainkan sebuah pandemi sehingga WHO (World Health Organization) sebagai organisasi kesehatan dunia memberlakukan physical distancing untuk menekan penyebaran virus tersebut. Seperti halnya yang pada lingkungan warga RT.4 RW.4 Kel. Jati Kec. Mayangan Kota Probolinggo yang sampai ini masih menerapkan program pemberlakuan pembatasan kegiatan masyarakat berbasis mikro (PPKM Mikro) sehingga seluruh aktivitas masyarakat sifatnya adalah terbatas.

Adanya kebijakan dari pemerintah utnuk memberlakukan physical distancing tersebut juga turut memberikan dampak bagi masyarakat, salah satunya yaitu pelayanan di fasilitas kesehatan. Saat ini pelayanan kesehatan hampir seluruhnya berfokus pada pengobatan dan perawatan dari pasien Covid 19 serta pemberlakuan physical distancing, tentunya hal ini sangat berpengaruh pada pemenuhan fungsi fasilitas pelayanan kesehatan dalam memberikan edukasi kesehatan. Edukasi kesehatan dirasa sangat penting terkait kegiatan pelayanan kesehatan yang diberikan sehingga dapat diwujudkan rasa saling percaya antara tenaga kesehatan dan pasien terutama mengenai prosedur tindakan medis pada fasilitas pelayanan kesehatan tersebut yang sangat beresiko bagi pasien itu sendiri.

Sehubungan dengan permasalahan tersebut, pihak STIKes Panti Waluya Malang melaksanakan kegiatan pengabdian kepada masyarakat dalam memberikan pembinaan, pendampingan dan konsultasi terkait tindakan medis dan persetujuannya serta prosedur pelaksanaan informed consent yang benar sehingga dapat digunakan untuk meningkatkan pelayanan kesehatan masyarakat terutama mengenai perlindungan hukum terhadap pasien secara berkelanjutan pada fasilitas pelayanan kesehatan.

\section{METODE}

Pelaksanaan kegiatan pengabdian masyarakat ini berlangsung selama 3 kali pertemuan kepada warga RT.4 RW.4 Kel. Jati Kec. Mayangan Kota Probolinggo yang 
berjumlah sebanyak 26 orang. Karakteristik warga diantaranya merupakan bapak-bapak dan ibu-ibu yang aktif pada berbagai kegiatan kesehatan dan kemasyarakatan. Adapun warga yang memiliki pekerjaan sebagai tenaga kesehatan sebanyak 2 orang. Metode pelaksanaan dilakukan dengan cara memberikan penyuluhan dan pendampingan serta diskusi online kepada warga. Adapun pelaksanaan kegiatan tersebut dimulai dari tahap persiapan, tahap pelaksanaan dan tahap evaluasi.

Tahap persiapan dilakukan dengan mengurus birokrasi dan permohonan ijin kepada pihak terkait, pertemuan dengan tokoh masyarakat dan petugas kesehatan, mengobservasi prosedur pelayanan kesehatan antara tenaga kesehatan dan pasien.

Tahap pelaksanaan dilakukan dengan memberikan sosialisasi bagi tenaga/kader kesehatan dan masyarakat secara daring melalui grup WhatsApp mengingat dalam kondisi pandemi Covid 19, mengenai pengertian tindakan medis di pelayanan kesehatan, pelaksanaan informed consent di fasilitas kesehatan serta selanjutnya memberikan contoh bentuk da nisi dari informed consent pada fasilitas pelayanan kesehatan.

Tahap evaluasi dilakukan untuk menilai tingkat pemahaman kader dan warga terkait pemahaman tentang pengertian tindakan medis, prosedur penggunaan informed consent serta isi dari informed consent pada fasilitas pelayanan kesehatan. Evaluasi dilakukan melalui tanya jawab langsung pada awal penyuluhan dan post test dilakukan pada akhir tahap penyuluhan.

\section{HASIL DAN PEMBAHASAN}

HASIL

Distribusi Peserta berdasarkan jenis kelamin dapat dilihat pada tabel 1 berikut:

Tabel 1. Distribusi Frekuensi peserta PkM Berdasarkan Jenis Kelamin

\begin{tabular}{llll}
\hline No. & Jenis Kelamin & Frek. & Prosentase \\
\hline 1. & Laki-laki & 13 & $50 \%$ \\
2. & Perempuan & 13 & $50 \%$ \\
\hline & Total & 26 & $100 \%$ \\
\hline
\end{tabular}

Distribusi Peserta berdasarkan profesi dapat dilihat pada tabel 2 berikut:

Tabel 2. Distribusi Frekuensi peserta PkM Berdasarkan Profesi

No. Profesi $\quad$ Frek Prosentase

\begin{tabular}{llcc}
\hline 1. & $\begin{array}{l}\text { Tenaga } \\
\text { Kesehatan }\end{array}$ & 2 & $7,7 \%$ \\
2. & Pedagang & 11 & $42,4 \%$ \\
3 & Pekerja Kantor & 6 & $23 \%$ \\
$4 . \quad \begin{array}{l}\text { lbu Rumah } \\
\text { Tangga }\end{array}$ & 7 & 26,9 \\
\hline & Total & 26 & $100 \%$ \\
\hline
\end{tabular}

Berdasarkan tabel 1, dapat dilihat jumlah peserta yang mengikuti kegiatan ini dengan jenis kelamin laki-laki dan perempuan masing-masing sebanyak 13 orang. Berdasarkan tabel 2, adapun jenis pekerjaan dari peserta kegiatan ini yaitu tenaga kesehatan sebanyak 2 orang, pedagang sebanyak 11 orang, pekerja kantor sebanyak 6 orang dan ibu rumah tangga sebanyak 7 orang.

Hasil kegiatan pada tanggal 1 Agustus 2021 terkait penyampaian materi tentang pengertian tindakan medis dengan metode ceramah dan tanya jawab berhasil dilaksanakan dengan indikator peserta mampu memahami materi yang disampaikan secara umum. Selanjutnya, hasil kegiatan pada tanggal 7 dan 11 Agustus 2021 terkait prosedur pelaksanaan informed consent dan pemberian contoh bentuk dan isi dari informed consent di fasilitas kesehatan melalui metode pemberian materi dan video pembelajaran serta tanya jawab secara online juga berhasil dilaksanakan dengan indikator peserta mampu mengerti materi tentang prosedur pelaksanaan penggunaan informed consent beserta bentuk dan isinya pada fasilitas kesehatan. Hasil tanya jawab online melalui grup WhatsApp dapat dilihat pada gambar berikut:

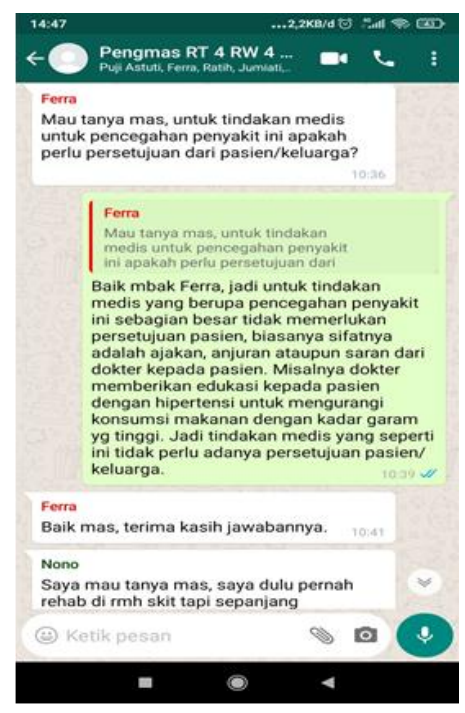

Gambar 1. Tanya jawab tentang jenis Tindakan Medis 


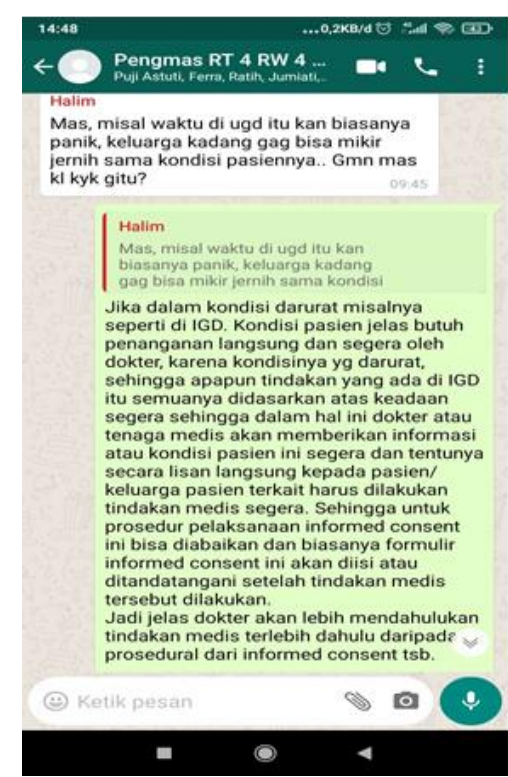

Gambar 2. Tanya jawab tentang Prosedur Pelaksanaan Informed Consent

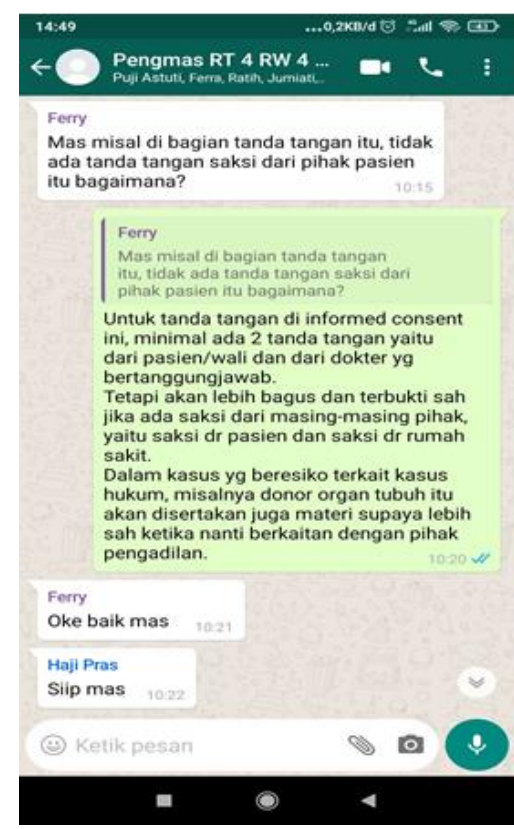

Gambar 3. Tanya jawab tentang Bentuk dan Isi Informed Consent

Distribusi Peserta berdasarkan pemahaman materi dapat dilihat pada tabel 3 berikut:

Tabel 3. Distribusi Frekuensi peserta PKM Berdasarkan Pemahaman materi

\begin{tabular}{cccc}
\hline No. & Pemahaman & Frekuensi & Prosentase \\
\hline 1. & Baik & 15 & $57,69 \%$ \\
2. & Cukup & 7 & $26,92 \%$ \\
3 & Kurang & 4 & $15,38 \%$ \\
\hline \multicolumn{2}{c}{ Total } & 26 & $100 \%$ \\
\hline
\end{tabular}

Berdasarkan tabel 3 , dapat dilihat pemahaman materi peserta setelah mengikuti kegiatan ini yaitu dengan pemahaman materi dengan kategori baik sebanyak 15 orang, kategori cukup sebanyak 7 orang dan kategori kurang sebanyak 4 orang.

\section{PEMBAHASAN}

Pada gambar 1, terdapat pertanyaan dari peserta yang mewakili tenaga kesehatan setempat yang bertanya terkait persetujuan tindakan medis untuk jenis tindakan pencegahan penyakit. Dari pertanyaan peserta tersebut, dijawab oleh pemateri bahwa tindakan medis yang dilakukan oleh dokter kepada pasien dalam hal untuk pencegahan penyakit biasanya bersifat ajakan, anjuran ataupun saran sehingga tidak perlu dilakukan persetujuan medis secara tertulis namun bisa melalui lisan saja, hal ini sudah sesuai dengan yang disampaikan pada (Depkes RI, 2008a).

Tindakan medis adalah tindakan profesional oleh dokter terhadap pasien dengan tujuan memelihara, meningkatkan, memulihkan kesehatan, atau menghilangkan atau mengurangi penderitaan. Tindakan medik adalah suatu tindakan seharusnya hanya boleh dilakukan oleh para tenaga medis, karena tindakan itu ditujukan terutama bagi pasien yang mengalami gangguan kesehatan. Suatu tindakan medis merupakan keputusan etik karena dilakukan oleh manusia terhadap manusia lainnya, yang memerlukan pertolongan dan keputusan tersebut berdasarkan pertimbangan atas beberapa alternatif yang ada. Menurut (Wiradharma, 2014), suatu tindakan medis tidak bertentangan dengan hukum apabila memenuhi syarat-syarat yaitu memmpunyai indikasi medis, untuk mencapai suatu tujuan yang konkret, dilakukan menurut aturan-aturan yang berlaku dalam ilmu kedokteran dan tentunya sudah mendapat persetujuan dari pasien baik berupa lisan maupun tertulis.

Pada gambar 2, terdapat pertanyaan dari peserta yang mewakili warga terkait penggunaan informed consent dalam keadaan gawat darurat. Dari pertanyaan peserta tersebut, dijawab oleh pemateri bahwa dalam kasus gawat darurat penggunaan informed consent dapat diabaikan terlebih dahulu dan mendahulukan tindakan medis untuk menolong nyawa pasien, pernyataan ini sudah sesuai dengan yang disampaikan pada pasal 4 (Depkes RI, 2008b). Informed consent merupakan hal mutlak diperlukan bagi pihak dokter sebelum ia melakukan tindakan medis bagi pasiennya yang diatur di dalam (DPR RI, 2009) Tentang Kesehatan Pasal 8, (DPR RI, 2004) Tentang Praktik Kedokteran Pasal 45 dan (Depkes RI, 2008a) Tentang Persetujuan 
Tindakan Kedokteran Pasal 2 ayat 1. Tindakan medis yang dilakukan oleh dokter tanpa adanya informed consent bagi pasien yang kondisinya gawat darurat dapat dilakukan, karena adanya pengecualian yang diatur pada penjelasan Pasal 45 dan Pasal 51 huruf d UU Praktik Kedokteran serta pasal 4 ayat 1 Permenkes. Semua itu didasarkan demi kesembuhan dan keselamatan pasien itu sendiri dan juga merupakan penerapan asas perlindungan dan keselamatan pasien yang dianut pada UU Kesehatan maupun UU Praktik Kedokteran. Persetujuan tindakan medis untuk pasien yang berada dalam unit gawat darurat berbeda dengan pasien secara umum, seorang pasien dalam kondisi darurat apabila sudah berada di dalam rumah sakit maka persetujuan tindakan medis dapat diabaikan.

Pada gambar 3, terdapat pertanyaan dari peserta yang mewakili warga terkait autentikasi saksi dari pasien dan rumah sakit dalam informed consent. Dari pertanyaan peserta tersebut, dijawab oleh pemateri bahwa dalam informed consent minimal ditandatangani oleh 2 orang yaitu pasien atau keluarga pasien dan dokter yang bertanggungjawab, tanda tangan saksi dari pihak pasien dan juga saksi dari pihak rumah sakit merupakan pelengkap keabsahan jika nantinya terjadi sesuatu sehingga tindakan medis tersebut berkaitan dengan kasus hukum akan lebih mudah untuk mencari saksi dalam pengadilan, pernyataan ini sudah sesuai dengan (Sitohang, 2017) bahwa hubungan hukum antara dokter dengan pasien timbul karena adanya kesepakatan kedua belah pihak atau didasarkan kepada perjanjian di antara mereka, hal ini tertera dalam autentikasi atau tanda tangan pada informed consent. Pada beberapa kasus sebagai alat bukti dalam pengadilan, formulir informed consent membutuhkan adanya materai yang disertakan dalam tanda tangan antara dokter dengan pasien atau keluarga/pasien.

Kegiatan pengabdian kepada masyarakat mengenai prosedur pelaksanaan informed consent pada fasilitas kesehatan di RT.4 RW.4 Kel. Jati Kec. Mayangan Kota Probolinggo secara daring ini telah berhasil dilaksanakan. Hasil evaluasi setelah dilaksanakannnya kegiatan pengabdian kepada masyarakat ini didapati masih adanya warga yang belum memahami prosedur pelaksanaan informed consent di fasilitas kesehatan tersebut sebanyak $15,38 \%$. Hal ini sangat wajar karena materi yang disampaikan adalah pengetahuan yang baru dan diperlukan ketekunan dalam memahami prosedur pelaksanaan informed consent tersebut. Namun, dalam implementasi pelaksanaan informed consent pada fasilitas kesehatan ini perlu adanya kepedulian dan perhatian dari para tenaga/kader kesehatan serta warga masyarakat sebagai pasien dalam hal pemahaman terkait tindakan medis dan persetujuan medis antara dokter/tenaga kesehatan dengan pasien sehingga dapat terciptanya rasa saling percaya terkait tugas dan fungsi masing-masing.

Oleh karena itu, perlu suatu inisiatif atau kesadaran dari para tenaga/kader kesehatan untuk bisa berkomunikasi aktif kepada pasien sehingga pasien dapat memahami hak dan kewajibannya dalam sebuah pelayanan medis melalui penggunaan persetujuan tindakan medis sehingga tercapai derajat pelayanan fasilitas kesehatan yang baik dan berkualitas khususnya dalam pelaksanaan informed consent pada fasilitas kesehatan.

\section{SIMPULAN DAN SARAN}

Pengabdian kepada masyarakat dengan judul "Pelatihan dalam Penggunaan Informed Consent Pada Fasilitas Pelayanan Kesehatan" yang dilakukan di RT.4 RW.4 Kel. Jati Kec. Mayangan Kota Probolinggo telah selesai dilaksanakan secara daring dengan pemberian materi secara online melalui grup WhatsApp, tanya jawab online dan akses video pembelajaran. Hasil dari kegiatan yaitu peserta diantaranya tenaga/kader kesehatan dan warga masyarakat sudah mampu untuk mengerti mengenai pengertian tindakan medis dan pelaksanaannya, prosedur pelaksanaan informed consent yang baik dan benar serta bentuk dan isi dari informed consent pada fasilitas kesehatan. Selanjutnya, secara berkesinambungan agar petugas kesehatan yang ada di lingkungan warga dan tempat kerjanya dapat memberikan contoh dalam menggunakan informed consent yang baik dan benar untuk ikut meningkatkan mutu pelayanan kesehatan yang berkelanjutan.

\section{UCAPAN TERIMAKASIH}

Pengabdi mengucapkan terima kasih kepada warga dan Ketua RT.4 RW.4 Kel. Jati Kec. Mayangan Kota Probolinggo yang bersedia menjadi subjek binaan dalam pengabdian kepada masyarakat ini. Tidak lupa pula pengabdi mengucapkan terima kasih kepada Lembaga Penelitian dan Pengabdian Kepada Masyarakat STIKes Panti Waluya Malang yang membiayai pengabdian kepada masyarakat ini.

\section{DAFTAR RUJUKAN}

Dali, Muh Amin, E. (2019). Aspek Hukum Informed Consent dan Perjanjian Terapeutik. Akademika Jurnal UMGo, 8(2). 
Depkes RI. (2008a). Peraturan Menteri Kesehatan No.290 tentang Persetujuan Tindakan Medis.

Depkes RI. (2008b). Peraturan Menteri Kesehatan Republik Indonesia Nomor: 269/MEN.KES/PER/III/2008 Tentang Rekam Medis.

DPR RI. (2004). Undang-Undang No. 29 tentang Praktik Kedokteran.

DPR RI. (2009). Undang-Undang Dasar Negara Republik Indonesia No. 36 tahun 2009 tentang Kesehatan.

Sitohang, O. E. (2017). Kajian Hukum Mengenai Persetujuan Tindakan Medis (Informed Consent) Dalam Pelayanan Kesehatan Ditinjau Dari Aspek Hukum Perjanjian. Lex Crimen.

Wiradharma, D. (2014). Tindakan Medis Aspek Etis dan Yuridis. Penerbit Universitas Trisakti. 